\title{
THE REUSE OF MUNICIPAL WASTEWATER IN SOILS
}

\section{KALAVROUZIOTIS I.K. ${ }^{*}$}

Received: 03/04/2014

Accepted: 19/05/2015

Available online: 18/06/2015
* School of Science and Technology, Hellenic Open University Tsamadou 13-15 \& Saint Andrea, 26222 Patras, Greece

*to whom all correspondence should be addressed: e-mail: ikalabro@yahoo.com

\section{ABSTRACT}

The idea of wastewater application on soils, returned to Western Hemisphere during 1950-60. Modern living requires an increased per capita use of water for coverage of individual needs. Nowadays, two main principles related to water management seem to gain the attention of both the scientific communities and the stakeholders: 1.water saving in irrigation of agricultural crops without the reduction of food production, and 2 . water saving during human use and industrial activity can only be promoted through water recycling. The increasing water demands at the level of Mediterranean countries are continuously intensified, because of the influence of a number of factors such as agricultural use and industrial consumption. The reuse of municipal wastewater in Mediterranean countries is now considered a useful practice. Countries such as Cyprus, Israel, Italy, Spain, France, Egypt, Tunisia, Morocco, and Greece, reuse the treated wastewater to a greater or a lesser extent in agriculture. There are several advantages and disadvantages in the proposed practice. However, existing technologies can help overcome such problems as for example the degradation and thus, the removal of pharmaceutical and xenobiotic compounds.

Keywords: wastewater treatment, wastewater reuse, irrigation practice, Mediterranean countries, wastewater disposal, greywater

\section{Historical review and practice}

Archeological findings have shown that the transfer of municipal wastewater, as well as, its disposal, was a common practice since the ancient years. Since the New Palace period (1700-1450 B.C), irrigation systems were constructed with well known that of "Linia" that is in the Lassithi Plateau. At this point numerous drainage channels and irrigation grooves intersect and create a remarkable figure. It is considered that the same technique has been transferred from the Minoans to Central Greece. During the period (3000-1100 B.C.), there has been evidence for the use of wastewater for irrigation of crops (Angelakis et al., 1996).

Archeological and other testimonies indicate that in Crete, during the Middle Minoan Period (2000-1600 B.C.), advanced plumbing and sanitary techniques were applied for water management of Minoan Settlements. These include the construction of aqueducts, wells, reservoirs and other hydraulic technologies, water systems, the construction and use of spring spa, and other sanitary facilities as well as drainage systems and disposal of wastewater and rainwater. The hydraulic and architecture operation of both irrigation and drainage systems, at palaces and settlements, considered as the one of the most remarkable features of Minoan Civilization. These systems were so advanced, that could be compared with the corresponding modern systems, which were introduced until the second half of the 19th century in European and American cities (Angelakis and Spyridakis, 2010). 
However, the concept of the systematic collection of wastewater for each community, regarding its treatment and disposal, has not been paid serious attention by mankind until the end of $19^{\text {th }}$ Century. Since then, for over a century, many large urban centers around the world, have implemented the disposal of wastewater. Remarkable examples are "the wastewater farms" Paris (1869), Berlin (1874), Melbourne (1896), as reported by Jewell et al. (1979). The first that applied wastewater to soil, support the use of soil as a medium treatment measure and wastewater as a source of plant nutrition. While the application to the soil surface was a process of high cost, most of the first systems had so many problems that contamination was extensive (Jewell et al., 1979). Because of all these problems, engineers turned to other areas so as to resolve the problem of wastewater disposal (Chase, 1964a).

The idea of the application of wastewater on soils, returned to Western Hemisphere during 1950-60. The quality of treated effluent gradually developed into an attractive method for irrigation of arid and decertified areas of the world. The treated effluents could be used as supplements to the growing need for water irrigation. Scientific and mainly engineering research was focused on issues that had direct relation with the plumbing of wastewater and other sectors, such as Public Health. At that time, the conditions had changed. Contrary to the first use, most of the treatment systems were successful because the hydraulic and assimilation properties of pollutants in soils were comprehensible. Many of these difficulties, caused by the increase of pollutants were treated with appropriate treatment of wastewater before the application of loads on soil. The soil could act as an effective treatment system to weaken the contaminants of sewage. There are more than 300 application sites of wastewater in U.S.A. (Jewell et al., 1979). In developing countries the application to the soil, of municipal wastewater has been the primary way to meet the needs for irrigation of crops (Kansel et al., 1983; Abdel-Reheem et al., 1986; Bahri et al., 1988; Zhang et al., 1989).

\section{The modern era}

Modern living requires an increased per capita use of water for coverage of individual needs. The average amount of consumption today is about 200 liters per capita / day. Food production today makes it necessary to increase consumption of water for agricultural crops. In agricultural production and in handling, development, and maintenance of green, less and less water is available. Thus, water saving should be methodized with priority to these uses.

The introduction of agricultural activities using biotechnical tools led to a vertical reduction in water consumption by agriculture. Wastewater recycling led to the development of urban and peri-urban green infrastructure and agricultural crops. The recycling of the municipal wastewater represents a beneficial opportunity in water supplies sector because:

1. It provides a second use of water supply as water irrigation and substitutes the use of precious drinking water.

2. A universal decontamination is promoted, because all the contaminant loads, mainly transported by water are treated.

The increase in the population and the significant rise in living standards cause a large increase in water demand, constantly reducing stocks of clean water and increasing stocks of reused water. In this way, the recycling of reused water becomes necessary, after appropriate treatment, which will contribute to the increase of water supplies and confrontation of any potential water crisis (Drakatos et al., 1996). Addressing the problems that are related to design, construction, and operation of treatment facilities, and disposal of municipal wastewater and industrial sewage, dictates the possibility of assessment of all the influence of human activity on nature. This assessment can be achieved through ecological indices (Babizos, 1985).

For example, the population in Greece is determined by the concentration of nearly half the population $58 \%$ in urban centers and dispersion of the rest in communities and municipalities with population under 10.000 residents. The collapse of productive system in small communities and the unscheduled enlargement of urban centers cause effects on the condition of the environment. These effects are 
important for regulating the natural environment, air pollution in large urban centers and pollution and contaminative load of both underground and surface water. With the entry of the new millennium, the new regional decentralization created new population strong municipalities, with equivocal up to now, results, with regard to the conservation of the rural population in the rural countryside.

The cultivated areas in Greece are 39.353 thousands of acres. Only $40 \%$ of it is irrigated, meaning that there is still a long way to go, until the desired irrigation levels of the crops are reached. In Table 1 , the data of irrigated land for the period: 1987-1993 is shown.

Table 1. Cultivated- Irrigated Lands of Greece (in thousands of acres)

\begin{tabular}{|c|c|c|c|c|c|c|}
\hline Year & $\begin{array}{l}\text { Cultivated } \\
\text { land }\end{array}$ & $\begin{array}{l}\text { Irrigated } \\
\text { land }\end{array}$ & $\%$ irrigated & $\begin{array}{l}\text { Fallow land } \\
\text { (1-5 years ) }\end{array}$ & 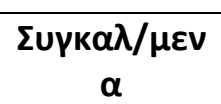 & $\begin{array}{c}\text { Agricultural } \\
\text { land }\end{array}$ \\
\hline 1987 & 35.504 & 11.560 & 33 & 4.613 & 718 & 39.399 \\
\hline 1988 & 35.384 & 11.608 & 33 & 4.654 & 708 & 39.330 \\
\hline 1989 & 35.260 & 11.984 & 34 & 4.754 & 660 & 39.354 \\
\hline 1990 & 35.098 & 11.830 & 34 & 4.932 & 694 & 39.336 \\
\hline 1991 & 35.172 & 11.900 & 34 & 4.858 & 726 & 39.304 \\
\hline 1992 & 35.102 & 12.592 & 36 & 4.820 & 511 & 39.411 \\
\hline 1993 & 34.932 & 13.145 & 38 & 4.943 & 524 & 39.353 \\
\hline
\end{tabular}

\section{Municipal wastewater and sewage}

In Greece, the environment in large urban centers is under serious pressure mainly by urbanization and activities that are linked to the functioning of the cities, while the natural environment, in most of the country, is in satisfactory condition in relation to West Europe and developing countries. Water pollution increases the cost of water treatment for irrigation and industrial uses and restricts the use of the coast for recreation and fish farming. It effects the primary production and processing, restricts the appropriate venues for productive activities and adds to the cost of production with the costly operation of sewage management systems, wastewater, and waste.

Wastewater is the grey water of urban origin. It consists of water that has been biologically used by human organisms and rejected as discharge as well as, the water used in normal housework uses. Wastewater as formed in a city, is gathered in the sewers or concentrated in tanks. Sewers lead to aquatic recipients, rivers, lakes or the sea, where pollution loads are poured there after wastewater purification can be tolerable for recipient or without purification can prove to be pollution loads which biologically kill the recipient.

In wastewater, apart from the pollution loads there are also accumulated pathogens, mainly derived from humans. In human feces which are in anaerobic biological situation the bacteria are mainly anaerobic. Effluents from sewers, contain aerobic microorganisms which change with pollution load, the flow of wastewater, and changes in temperature. In wastewater, the aerobic bacteria are found to be tripled during summer compared to winter. This is attributed to variable human metabolism behavior during summer and winter periods. However, proportionate differentiations are also shown after the temperature changes of sewage between summer and winter period and this affects the activity of wastewater.

Municipal wastewater is created by human activity and domestic life basically, as it has already been referred, as well as industrial activities. Municipal wastewater is also, differentiated by city, country and agricultural area. The polluting loads in wastewater of Mediterranean cities, are increased particularly in solids, or polluting loads in sepsis, because in the large length of sewers with high local temperatures are created active biological conditions with quick oxygen consumption.

The biological action in the sewers has to be maintained aerobic, and this is a condition of the sewer design, because if the conditions prevailed are anaerobic, smelly sewers will be created and the gases 
produced will erode the concrete sewage pipelines. The sewage has colloidal nature. The composition of sewage makes it difficult to be transported by pipelines, because each flow, emerges smell and emit methane which at concentrations above $7 \%$ in air, leads to explosion.

Additionally, the suspended organic and inorganic materials strain the pipelines with fertilization and frictions. The sewage are created in those cities which do not have full coverage with drainage nets.

The average quantity of wastewater that is daily drained off by humans, depends on many factors, the most important of which is the abundance or lack of water in the house, and the area, the cost of water, the cultural level, economic situation etc. Wastewater is presented as multiphase mixtures that coexist with solids, perfect solutions and colloidal dispersions.

The main wastewater constituent is $\mathrm{H}_{2} \mathrm{O}$. pH of wastewater is almost neutral (7). Its temperature is some degrees greater than the average air temperature in winter and somewhat lower than that in summer. The organic compounds in the wastewater (fresh mixture) are:

a) Proteins: $40-60 \%$

b) Carbohydrates: $25-50 \%$

c) Fatty Compounds: $10 \%$

These organic compounds coexist with the products of their decomposition, such as amino acids, ammonia, hydrogen sulfide, methane, hydrogen and with various other organic compounds, detergents, orthophosphate etc.

The determination of the contaminant concentration in wastewater is done with the known techniques of analytical chemistry. Organic compounds are historically determined with indirect methods. The most common indirect determination of the organic compound contents of wastewater are the determination of the Total Organic Carbon, known as TOC, Chemical Oxygen Demand, known as COD and Biochemical Oxygen Demand, known as BOD. BOD is an ordinary indirect determination of the part of the organic compounds of wastewater which are decomposed by metabolic processes aerobic microorganisms, natives of water after some time.

Wastewater is industrial runoff, which usually consists of water that has been burdened with energy (usually temperature) or byproducts or co products of productive procedure in a non- economically exploitable grade and must be disposed by removal from the place of their generation. Except for wastewater there are various other liquid substances for rejection. The quantity, the provision, and content of industrial runoff varies and is dependent on the adopted production processes, technology that is used in each factory etc. Thus, the existing reports have orienting character. Lastly, the organic and inorganic load of wastewater, varies both in terms of absolute values and in concentrations, not only from industry to industry, but also in the same industry from hour to hour.

\section{Sewage and wastewater disposal}

Municipal wastewater can soon be disposed in the topsoil, in streams, lakes, or into the sea after a license that is granted by competent authorities. Specifically, for the tourist installations the disposal of wastewater in the sea (regardless of the degree of purification) is not permitted, apart from the exceptional case in which the disposal is technically impossible to be in the soil surface or subsoil. The increase in the size of urban centers and intensity of production processes highlighted the necessity for the protection of the liquid environment from contamination and pollution. As it was mentioned above, legislation forbids disposal of wastewater without prior authorization.

Authorization is granted by competent authorities on the basis of the protection of both abstraction sources and public health generally, and the possibility of further use of waters which have received sewage, as well as the protection of aquatic recipient from contamination. For wastes of production procedures (including both the agricultural and livestock activities), general treatment is required before their final disposal. Quality standards of wastewater and sewage for final disposal are specified according to legislation and to the decisions of municipalities or drainage organizations. 
Sewage or wastewater which has undergone treatment at least equivalent to screening and two-hour sedimentation, can be disposed in accordance with EIB /221/1965 sanitary provision in the soil surface. The disposal site in accordance with the sanitary provision, mentioned above, and the limits must be at least $30 \mathrm{~m}$ from wells and sources and $15 \mathrm{~m}$ from water pipelines.

In areas, where there is surface disposal of greywater, tree crops and the cultivation of ornamental plants are permitted. The disposal of greywater in the soil surface can be carried out through the system of artificial rain, with irrigation ditches, periodic flooding etc, as long as the absorption of hydraulic and assimilation of pollution load of wastewater from the soil are ensured. If the available for disposal greywater has not undergone adequate treatment, odor problems are created, particularly if the disposal is done with artificial rain. A membrane of biological aggregates in the soil is created and gradually increases in thickness, reducing the absorptive capacity of the soil.

The receptive capacity of the soil in hydraulics and pollution loads is dependent on the type and the use. The disposal of treated and non treated greywater in the soil is an attractive management solution of the dirty ones, which ensures without considerable expenses and difficulties, the effective recycling of water and pollution load. Limiting factors are the large requirements for land which should be developed in disposal fields, combined with the high price of land and the prejudices of the authorities and the population for wastewater management.

The increase in water consumption in Greece for basic uses (water supply, irrigation, industrial use) caused the increase of discarded waste which is gradually varied, enriched with more pollutants, creates the necessity for treatment with more complex procedures. The discharge of used water is usually done:

(a) In soil, in rural settlements, straight through absorbent tanks or after the inserting of septic tanks (which are neither maintained nor monitored, so that after some time to function as a body and be a kind of absorbent tanks).

(b) To receivers like streams, tributaries, rivers, that flow into the sea, and in some cases through small torrents or through lakes, after a certain degree of purification.

This situation has created a significant pollution problem of water bodies as well as marine and estuarine areas. In islands, the disposal of treated wastewater in the sea does allow its use in secondary applications which cannot be covered with completely pure water due to its continuous decrease. Large evaporation and groundwater pumping causes aquifer level to continuously descend.

The disposal of used wastewater to receivers causes pollution problems due to transferred pollutant loads. The used wastewater is derived:

(a) From wastewater absorbent tanks through sewage filtration.

(b) From municipal wastewater which is drained in recipients after purification, so as to satisfy the allowable quality of the basic parameters of pollution $\left(\mathrm{BaO}_{3}, \mathrm{~N}, \mathrm{P}, \mathrm{NH}_{3}\right.$, Coliform bacteria /100ml).

(c) From disposal of industrial wastewater, after purification.

Thus, the presence of small water supplies in most receivers causes problems of dilution of used waters, disqualifying the acceptable use of the receivers (water supply, swimming, fishing, irrigation, general use).

\section{The reuse as irrigation practice in mediterranean countries and in the world}

In modern era, many countries and particularly those from the Mediterranean basin are facing problems from lack of sufficient water and water quality degradation. The problems are expected to intensify in the next decades and this is due to the projected increase of population at international level, therefore, the expected increase in average per capita water use (Asano, 2003; Asano et al., 2006; Angelakis et al., 1998). If these phenomena are combined with the extremely limited quantity of natural water in our planet, make imperative the need of developing control systems and wastewater management (Tsakiris, 1995). The increasing water demands at the level of Mediterranean countries are continuously intensified, because of the influence of a number of factors such as agricultural use and industrial consumption. Also, 
the improvement of life quality, the over pumping of underground aquifer, and the huge misdistribution of atmospheric precipitation, because of climate change, burden the existing adverse conditions.

The reuse of municipal wastewater in Mediterranean countries, has been proposed by Bazza (2002) and is now considered a useful practice. Countries such as Cyprus, Israel, Italy, Spain, France, Egypt, Tunisia, Morocco, and Greece, reuse the treated wastewater to a greater or a lesser extent in agriculture. Generally, the reuse in these countries is as follows:

1. Cyprus. $180 \mathrm{Mm}^{3}$ of wastewater that represents the $75 \%$ of the annual available amount is reused for irrigation goals in agriculture. The remaining $25 \%\left(60 \mathrm{Mm}^{3}\right)$ is reused in domestic industry or other purposes. The total reusable quantity of water resources $900 \mathrm{hm}^{3} /$ year: $67 \%$ surface and $37 \%$ underground water. The reuse of water promotes the environmental protection of coastal areas and provide water for landscape irrigation. The high production cost of recovered water is $7.5 \mathrm{cents} / \mathrm{m}^{3}$. The quality standards of recovered water are more stringent than the guidelines of WHO take into account the specific conditions of Cyprus. These include codes of practice (BMP) for agricultural irrigation based on $\mathrm{BOD}_{5}, \mathrm{SS}, \mathrm{FC}$, and intestinal nematodes. The treatment systems include territorial and secondary treatment, accompanied with disinfection and lagoons with extensive storage (Fatta-Kassinos et al., 2011).

2. Egypt. The reuse is an antique irrigation practice. It is currently calculated about $4930 \mathrm{Mm}^{3} /$ year of treated wastewater is reused, wastewater arising from the operation of 22 sewage station installations. It is worth mentioning that other 150 units of biological stations are under construction. The overall capacity of treated wastewater provision of existing operating sewage stations in Egypt is mounted to 1,752 billions $\mathrm{m}^{3} /$ year (FAO, 2000).

3. Morocco. The reused wastewater areas in year 1999 reached $546 \mathrm{Mm}^{3} /$ year and are expected to reach $900 \mathrm{Mm}^{3} /$ year, in year 2020 (El Atiri et al., 2002). The available wastewater resources are 30.000 $\mathrm{hm}^{3} /$ year $\left(22.000 \mathrm{hm}^{3}\right.$ surface and $8.000 \mathrm{hm}^{3} /$ year underground water). Water use is $11.500 \mathrm{hm}^{3} /$ year: $93 \%$ for irrigation of 1,2 million ha. Surface irrigation with underwater spray is used on large farms. In 1999, the provision of wastewater was $546 \mathrm{hm}^{3} /$ year and is expected to reach $900 \mathrm{hm}^{3} /$ year until 2020 .

4. Tunisia. The biological stations are concentrated in the coastal areas of Mediterranean. It has been reported that the total irrigable area which will be irrigated with treated wastewater will amount to 200,000 acres when the supply capacity of wastewater reaches $215 \mathrm{Mm}^{3} /$ year (Bahri, 2001).

5. France. The reuse of wastewater involves more than 300,000 acres and occurs in a wide range of applications, such as cultivation of cereal crops, orchards, vegetable species, and irrigation of parks and golf courses (Angelakis et al., 2002).

6. Italy. The corresponding applications concerns 400,000 acres. More specifically in the province of Emilia Romagna, for 2500 acres, approximately $450000 \mathrm{~m}^{3}$ / year are reused for irrigation. Recently, the reuse for irrigation is applied with success in Sicily and Sardinia (Lazarova, 2000). The reuse in Northern Italy was promoted for the protection of waste discharges, in the coastal areas of the Adriatic Sea. The soil treatment is considered as an additional tool for improving the quality for reuse and protection of water resources. Since 2000, many large systems have been built in South Italy with soil treatment and storage for agricultural and industrial uses (Lofrano and Brown, 2010).

7. Portugal. The reuse is expected to reach approximately $580 \mathrm{Mm}^{3} /$ year, quantity that is approximately twice than the current one. It is estimated that approximately $350,000-1,000,000$ acres could be irrigated with municipal wastewater (Angelakis et al., 2002).

8. Israel. The available amount of wastewater for reuse reaches 1.7 billions $\mathrm{m}^{3} /$ year and the rate that is being drained for irrigation amounts $64 \%$ (Shelef et al., 2002). In ten years, Israel recycled and reused for irrigation purposes approximately $70 \%$ of municipal wastewater, while in USA approximately $1 \%$ of the respective wastewater was reused (Avnimelech, 1996). The water crisis in Israel and the relatively low cost of reuse make this practice a very cheap source of water for Israel.

9. Spain. Water management is a decentralized process, held by Autonomous Communities (districts) and Hydrographic Confederation. A broad distribution in relation to water can be done, on the basis of the Atlantic and the Mediterranean. Due to climatic reasons, the main problems of water deficiency are found 
in the Mediterranean basin, considering that a large number of residents are living there with also large water requirements for irrigation. Additionally, tourist areas exist in the side of Mediterranean, where the water demand for irrigation increases in the summer months, putting a huge pressure on water resources, either in surface or underground waters. Locally, many underground waters have been exhausted and salinity problems appear along the Mediterranean coast because of salination. Sometimes, nitrate problems are also added in some areas, because of cattle. The reuse is promoted when the country suffers from significant drought, yet whenever the climate is favorable, the few initiatives that are carried out are targeted. Nevertheless, there are areas where the reuse is successful, particular in agriculture and irrigation of golf courses. Several cities use the recycled water for tree crops in municipalities and other urban uses, e.g. Palma de Magiorka and Madrid. In Valencia and Murcia regions with intense primary production, an important part of the wastewater produced, is recovered and reused for agricultural purposes (e.g. Orchards-citrus). Most of the golf courses in Catalonia, Murcia, Andalusia and Madrid are irrigated with recycled water (Pedrero et al., 2009).

10. Greece. It has been studied the reusability capability of wastewater in decertified areas, and became the design of 35 set of management plans in 13 districts of Country (Kalavrouziotis et al., 2001). Minimum areas are irrigated with WWTP and mostly crops that are not produced for human consumption e.g. cotton.

The reuse of treated wastewater is currently a routine practice in many countries of the world.

In China, almost $1.33 \times 10^{6}$ hectares of agricultural land are irrigated with non-treated wastewater or partially treated wastewater (Wang, 1983). In Mexico City, a metropolis of 15 million residents, more than 70.0000 hectares of arable land, are irrigated with treated wastewater (Vila Lobos et al., 1981). The reuse of municipal wastewater has also been reported in countries of Saudi Arabia, Iran, in South Africa, in the Netherlands and Germany (Heaton, 1981).

This use has become reality in California of USA since 1980. Up to 1987,63\% of the treated wastewater were used in agriculture. The majority of treated wastewater $(78 \%)$ is used in Central Valley and the Southern coastal areas of California. Throughout California, 200 wastewater treatment plants are operated and from this reuse of the treated wastewater in agriculture seems that 200 agricultural plant species are irrigated as well as 11 other non-food crops ( Table 2).

Table 2. Irrigated crops with treated wastewater in California

\begin{tabular}{cc}
\hline Fruit & Non Fruit \\
\hline Apple & Forage plants \\
\hline Asparagus & Cotton \\
\hline Avocados & Lakes \\
\hline Barley & Forest Species \\
\hline Beans & Vikos \\
\hline Cabbage & Oats \\
\hline Cauliflower & Eucalyptus \\
\hline Celery & \\
\hline Citrus & \\
\hline Lettuce & \\
\hline Corn & \\
\hline Peach & \\
\hline Peanut & \\
\hline Plum & \\
\hline Wheat & \\
\hline
\end{tabular}

The reuse of wastewater in most middle-east countries has been reported by Bazza (2002). Information about the disposal of the treated wastewater into Jordan are presented in Al-Salem (1987) and Saquaz (1990). 
In Japan, $1.09 \times 10^{10} \mathrm{~m}^{3}$ of wastewater are produced in 938 wastewater treatment plants (Maeda et al., 1994). From this quantity, $8.5 \times 10^{7} \mathrm{~m}^{3}$ are used for various purposes. Tokyo is one of the first cities in the world that has promoted the reuse of municipal wastewater. Due to the high population density, which is observed in Japan, the management of the defective water resources provides the increased recovery and the reuse of wastewater discharge, mainly for urban use. The prevailing tendency foresees the reduction of water demand with the reuse of recovered water for cleaning toilets, commercial stores, and school buildings. Tokyo is a very good model for urban cities in developing countries, as it is historically addressing the domestic use of water as essential and as a first priority need, in relation to other uses such as agricultural use (Angelakis et al., 1985).

\section{Advantages of wastewater reuse}

In areas where the climate changes, such as Greece, the rational use of wastewater, can contribute to avoid water scarcity and provide environmental protection. This is true only when the wastewater has undergone additional treatment disinfection so that the microbial load is within the planned, by international organizations, safety limits. The treated municipal wastewater has high concentration in nutrients (N, P) and in case of their reuse for irrigation, reduces the need for the application of inorganic fertilizers. This also makes unnecessary the extra treatment for removing nutrients that is required in the case of disposal of wastewater into recipients which may present eutrophication (sea, lakes).

The following example demonstrates agronomic and economic benefits from the use of wastewater for irrigation. A city of 500,000 inhabitants with water consumption $200 \mathrm{~L} /$ day/inhabitant produces approximately $85,000 \mathrm{~m}^{3} /$ day wastewater. Assuming that $85 \%$ of this quantity enters the sewer, then an applying irrigation of $500 \mathrm{~m}^{3} /$ acres/year could irrigate an area of approximately 60,000 acres, provided water storage during the non- irrigation season. Assuming that the average concentration of nutrients in wastewater per liter, is $35 \mathrm{mg}$ nitrogen, $10 \mathrm{mg}$ phosphorus, and $30 \mathrm{mg}$ potassium, which largely cover the requirements of these crops in these three nutrients.

The treated water in order to be used for irrigation has to be of suitable quality. After appropriate treatment, wastewater should not exceed the permissible limits content, including traces. For their growth, plants need a restricted number of traces, which should not exceed the permissible limits. With water disposal in the soil further purification is done at two levels from:

1. The plants that get the minerals they need for their growth and

2. The soil which favors the biodegradation of organic matter and retention of part of metal elements.

The reuse of wastewater will contribute to the decrease of water quantities which derive from pumping, from subsurface aquifers for irrigation crops, for industrial and hygienic use, provided that a series of chemical parameters would be studied, and especially the value of electrical conductivity EC and SAR (Sodium absorption ratio). Another way of finding enough water is the practice of municipal wastewater reuse, arising from outflows from wastewater treatment plants in small or large municipalities and administrative regions of Mediterranean countries.

These outflows can be used for irrigation, enrichment of the groundwater aquifer horizons, for industrial use, for domestic use, for ventilation, after they have undergone the appropriate level of treatment depending on the use which they are intended to be used for, to avoid risks for human health initially, and for the protection of the environment in general (Asano et al., 2006; Kalavrouziotis and Apostolopoulos, 2006). Additionally, the safe use of municipal wastewater may assist in reducing the amount of water needed, which is observed between the quantity demanded and the existing one. Moreover, the reuse helps to achieve the following main objectives: (a) the development of treated wastewater as irrigation water and (b) to avoid discharges into natural recipients (lakes, rivers, seas, streams), thereby reducing the possibility of contamination of both surface and underground waters (Asano, 1998). Basic principle of this practice should be that the municipality will use this water for any 
use needed, provided that it has undergone the appropriate degree of treatment and maintain the standards of quality which each use requires (Ayers et al., 1985).

The fact is that wastewater reuse is advantageous in that:

1. It is a source of irrigation water for crops, and other industrial and urban uses, such as the irrigation of parks and hedgerows, cleaning of trees, and communal toilets. Also, they contribute to the possibility of saving natural water and better manage natural water resources.

2. It contains nutrients for crops such as $\mathrm{N}, \mathrm{P}, \mathrm{K}, \mathrm{S}, \mathrm{Cl}, \mathrm{Fe}, \mathrm{Zn}, \mathrm{Mn}, \mathrm{Cu}, \mathrm{Mo}, \mathrm{B}$, and also improves soil fertility.

3. It supplies the soil with significant orphan substances which are necessary for good structure, ventilation, water retention, and generally for the improvement of soil productivity.

Besides the above advantages, wastewater reuse has disadvantages, such as:

1. Wastewater contains heavy metals ( $\mathrm{Cd}, \mathrm{Co}, \mathrm{Cr}, \mathrm{Mn}, \mathrm{Zn}, \mathrm{Ni}$, and $\mathrm{Pb}$ ), xenobiotic substances such as pesticides, toxic compounds that derived from organic compounds such as phenols, polycyclic hydrocarbons, as well as other pharmaceutical substances.

2. The above substances are not eliminated during secondary or higher treatment of wastewater thus, through the use of wastewater treatment plants, these are transported and dispersed in the environment and in sequence through plant products, are inserted in the food chain of both humans and animals.

3. Many heavy metals and xenobiotic substances, like chemical solutions of anthropogenic origin that are resistant to decay, such as dioxins, DDTs, polychlorinated biphenyls (PCBs), 3,5dichlorphenol, formaldehyde, 4-nitrophenol, dichloromethane.

4. Also, pharmaceutical products are accumulated to soil, which can potentially create significant environmental problems. Likewise, these substances can be transported to underground waters and eventually to drinking water with adverse effects for human health.

5. A large risk that involves wastewater treatment plants is that due to its contribution to decay of pharmaceutical substances in the environment, a matter of practical interest is created. Namely, the report of infectious bacteria in residual pharmaceutical substances could render them resistant to various antibiotics. To create resistant genes with serious effects on human health.

6. Because of the list of substances that may remain in the environment, nanoparticles cannot be eliminated, the release of heavy metals in the environment through the reuse which contain nanoparticles, can be hazardous to the effectiveness of micro-organisms, that are related to the natural cycle of elements, degradation and plant growth.

7. According to some recent researchers is noted that wastewater reuse facilitate the entrance of prohibited substances to soil and generally to the environment (Zuccato et al., 2008; Boleda et al., 2009). These substances arrive to the environment unchanged or slightly modified such as opiates, Canabinoids, Amphetamines, Cocaine, and other prohibited substances (Zuccato et al.,2008; Boleda et al., 2009).

8. Some crops can absorb and intake pharmaceutical substances during their growth which can be accumulated to various plant organs for instance in a greenhouse experiment with corn, it was found that pharmaceutical substances of lasalocid and Monensin were accumulated to corn plants.

9. Also in laboratory experiments, the absorption of the pharmaceutical substance sulfadimethoxin from peas, sorghum, and corn was observed. This absorption affected the plant growth (Schneider, 2008). The antibiotic Oxytetracycline acted toxically in the growth of the stem of the clover plant (Kong et al., 2007). Also, in other experiments the toxicity of Enrofloxacin antibiotic in clover plants (Lactuca sativa), beans (Phaseolus vulgaris), cucumbers (Cucumis sativus), and radishes (Raphanus sativus) was observed. 


\section{Removal of xenobiotics and pharmaceutical substances from wastewater}

Unfortunately the xenobiotics and pharmaceutical substances are not removed during the secondary and higher treatment of wastewater. Examples of xenobiotic substances, usually found in wastewater treatment plants (Fatta et al., 2011) include the following:

\begin{tabular}{|c|c|}
\hline 1. Erythromycine & 7. Atenolol \\
\hline 2. Amoxillin & 8. Propanolol \\
\hline 3. Ofloxacin & 9. Carbamazepine \\
\hline 4. Sulfamethoxazol & 10. Flutamide \\
\hline 5. Diclophenac & 11. Ketokonazol \\
\hline 6. Ibuprofen & 12. Ethinylestradiol \\
\hline
\end{tabular}

This is a serious problem because these substances may be transferred in the food chain through plants and may endanger public health. Yet, the great danger posed by reuse is to create resistance genes of pathogenic microorganisms in pharmaceutical substances, which are used to combat the ones that infect humans. As it is highlighted by Fatta et al. (2011), the influx of antibiotics in the environment through wastewater treatment plants is a practical issue of interest. Virulent bacteria in residual pharmaceutical substances can cause resistance to them, the combat of which in case of human infection can be very difficult. As a consequence of the above, the removal of all the xenobiotics and pharmaceutical substances must be done during wastewater treatment. Actually, some researchers have addressed this issue (Mascolo et al., 2010) and suggest the following removal methods, which are biological and physicochemical. The first is economic, yet not as effective, while the second is more effective, but costly. The operating mechanism of the removal processes has not been adequately studied.

The suggested removal methods are:

1. Absorption method with activated carbon (Tahar et al., 2013)

2. Method of advanced oxidation process (Ozonation, photolysis, heterogeneous photolysis, electrochemical oxidation, etc) (Mestre et al., 2009)

3. Use of trickling filter (Akker et al., 2008)

4. Use of rotating biological contractor, RBC (Palma and Verdone, 2009)

5. Use of fixed media submerged biofilter (Silvàn et al., 2010)

6. Use of granular medium biofilter (Oh et al., 2010)

7. Use of fluidized bed reactor (Aldaco et al., 2009)

8. Method of nitrifying recirculating biofilter, RBF) (Krkošek et al., 2014)

9. Use aerobic and anaerobic membrane combined $\mathrm{O}_{3} / \mathrm{H}_{2} \mathrm{O}_{2}$ ) (Xing et al., 2014)

10. Use of constructed wetlands (Li et al., 2014)

11. Adsorption method by zeolite (Taharet et al., 2014)

12. Farming methods of yeast fungus pollutant removal - oriented yeast biomass production (Yang and Zeng, 2014)

It is noted regarding removal method of pharmaceutical substances, that this is base on the type of the pharmaceutical substance. For instance buprophen and naproxen are removed through biotransformation, while gemfibrozil and dichlorophenac through absorption (Xing et al., 2014).

Some of the above methods are discussed in greater detail in the following paragraphs:

- Use of activated carbon filters (Tahar et al., 2013)

This method provides excellent adsorption capacity and removal of hydrophilic xenobiotics compared to other absorbent substances, which have been proposed at previous times.

- Method of nitrifying recirculating biofilters, RBF (Krlosek et al., 2014). 
The RBF method was used for removal of hydrogen pharmaceutical active compounds, such as Gemfiprozil, Naproxen, Ibuprofen, Dichlorofenac, treated by second degree of wastewater treatment plants. The average removal, ranged as follows: Ibuprofen 92-99\%, Naproxen 62-92\%, Gemfibrozil and Dichlorofenac 40-76\%.

- Method of aerobic and anaerobic membrane with $\mathrm{O}_{3} / \mathrm{H}_{2} \mathrm{O}_{2}$ (Xing et al., 2014).

The presence of the system $\mathrm{O}_{3} / \mathrm{H}_{2} \mathrm{O}_{2}$ effectively oxidizes all organic contaminants, including those of pharmaceutical and xenobiotic substances. The method has proved to be very effective for wastewater treatment of pharmaceutical industries.

- $\quad$ Absorption method by zeolite (Tahar et al., 2014)

Zeolite is used as absorption method of xenobiotics and pharmaceutical substances in the presence of clay, with very well results (Tahar et al., 2013). This method is proposed for the restoration of the activated carbon, which is very costly. Additionally this method is recommended as treatment of fourth degree

- Removal method of xenobiotics and pharmaceutical substances through production of yeast fungus (Yang and Zheng, 2014).

Yeast fungus developed in nutrient solutions of industrial wastewater contribute to protein production from unicellular organisms. This is an attractive purification method of wastewater from xenobiotics and pharmaceutical substances with simultaneous production of proteins from unicellular organisms. The use of yeast fungus in the treatment process of industrial wastewater of high carboxylation and rich in oils and high salinity assists in the removal of all xenobiotics and pharmaceutical substances because the proliferation of yeast fungus in industrial wastewater is accompanied with simultaneous distraction of the above substances, as well as of other useful substances. Simultaneously, yeast funguses restrict bacterial growth.

- $\quad$ Method of constructed wetlands (Li et al., 2014).

It is achieved with the assistance of specific man-made wetland. These wetlands attract the interest of researchers for the effective removal of xenobiotic and pharmaceutical substances. These can be used as an alternative removal method.

\section{Conclusions}

The main conclusions of the present study are as follows:

- Nowadays, there is a certain need for the reuse of treated wastewater.

- There are several advantages in terms of resource saving in wastewater reuse practice.

- There are several technologies that can help to overcome disadvantages related to wastewater reuse.

\section{References}

Abdel-Reheem M.A., Faltas R.C. and Ahmed W.E. (1986), Changes in trace elements in Sandy soil irrigated with sewage water, Bull. Faculty Agri. Cairo Univ., 37, 969-980.

Aldaco R., Garea A. and Irabien A. (2007), Calcium fluoride recovery from fluoride wastewater in a fluidized bed reactor, Water Research, 41, 810-818.

Al-Salem S.S. (1987), Evaluation of the AL Samra waste stabilization pond system and its suitability for unrestricted irrigation. Paper prepared for the land and water development division, FAO, Rome.

Angelakis A.N. and Spyridakis D.S. (2010) Water Supply and Wastewater

Angelakis A.N. and Rolston D.E. (1985), Transient movement and transformation of carbon species in soil during wastewater application, Water Resour. Res, 21(8), 1141-1148. 
Angelakis A.N., Bontoux L. and Lazarova V. (2002), Main challenges for water recycling and reuse in Eu countries, IWA regional symposium on water recycling in Mediterranean Region, Iraklio, Greece, 26-29 September, pp. 71-79.

Angelakis A.N., Marecos Do Monte M.H.F., Bontoux L. and Asano T. (1998), The status of wastewater reuse practice in the Mediterranean basin: need for guidelines, Water Research, 33(10), 2201-2217.

Angelakis A.N. and Spyridakis S.V. (1996), The status of water resources in Minoan Times, NATO Asiseries vol 36, chapter 8, pp.161-191.

Asano T. (1998), Wastewater Reclamation and Reuse, Book volume 10, Technomic Publishing, CancasterPennsylvania, U.S.A.

Asano T. (2003), Water Reuse: A Future Perspective. Water resources and Water Supply in the 21st Century, Hokkaido University Press, Saporo.

Asano T., Burton F., Leverenz H., Tsuchihashi R. and Tchobanoglou G. (2006), Water Reuse, Issues, Technologies and Applications, edited by Metcalf and Eddy, p. 1570.

Avnimelech Y. (1996) Wastewater recycling in Israel: Past, Present and Future, International water and engineering review, 17(9), 46-50.

Ayers R.S. and Westcot D.W. (1985), Water quality for agriculture, irrigation and drainage paper no. 29. Food and Agricultural Organization of the United Nations, Rome, Italy.

Bahri A. (2001), Water reclamation and reuse in Tunisia. Joint FAO/WHO consulation for launching the regional network on wastewater reuse. Amman, Jordan.

Bazza M. (2002), Wastewater recycling and reuse in the Near-east region: Experience and issues, IWA regional symposium on water recycling in Mediterranean Region, Iraklio, Greece, 26-29 september, pp. 43-59.

Chase E.C. (1964a), Nine decades of sanitary engineering, Part II- The awakening, Water work and waste engineering, 34(6), 48-49, 79.

Chase E.C. (1964b), Nine decades of sanitary engineering, Part III- Back to the land, Water work and waste engineering, 34(7), 49-50, 78.

Drakatos P.A., Fanariotu I. and Kalavrouziotis I.K. (1996a), Impact of wastewater irrigation and sludge utilization on mechanical properties of Eucalyptus Wood. Restoration and Protection of the Environment, Proceedings of the International Conference, Chania, Greece, 28-30 August,1996, pp. 723-726.

Drakatos P.A. and Kalavrouziotis I.K. (1996c), Impact of wastewater irrigation and sludge utilisation on thermal and acoustic properties of Eucalyptus Wood. International Workshop, Sewage Treatment and Reuse for Small Unities: Mediterranean and European Experience, November 23-26, 1996, Marocco, Africa.

Drakatos P.A., Varnavas S.P. and Kalavrouziotis I.K. (1996b), Irrigation of certain mediterranean plants with wastewater. Tolerance in heavy metals. Restoration and Protection of Environment, Proceedings of the International Conference, Chania, Greece, 28-30 August, 1996, pp. 412-418.

El Atiri R. and Rergini F. (2002), Wastewater reuse in the case of Tunisia. First WDM Forum on wastewater reuse, 10RC. Rabat, Morocco, 26-27 March.

Fatta-Kassinos D., Kalavrouziotis I.K., Koukoulakis P.H. and Vasquez M.I. (2011), The risks associated with wastewater reuse and xenobiotics in the agroecological environment, The Science of the Total environment, 409, 3555-3563.

Heaton R.D. (1981), Worldwide aspect of wastewater reclamation and reuse, pp. 43-74 in: DILTRI, F. M. (ed.). Municipal wastewater in agriculture. Academic press, New York.

Jewell W.J. and Seabrook B.L. (1979), A history of cand application as a treatment alternative: Technical report Epa 430/9-79-012. U.S. Environmental Protection Agency, office of water program operation, Washington. D. C.

Kalavrouziotis I.K. and Drakatos P.A. (2001), The future of irrigation by processed wastewater in Greece, Journal of Environmental and Waste Management, 4(2), 107-110.

Kalavrouziotis I.K. and Apostolopoulos C.A. (2006). An integrated environmental plan for the reuse of treated wastewater from W.W.T.P. in urban areas, Building and Environment, 42(4), 1862-1868.

Kansel B.D. and Singh J. (1983), Inffluence of the municipal wastewater and soil properties on the accumulation of heavy metals in plants, pp. 413-416, in Proceedings of international conferences of heavy metals in the Environment, Heidelberg, Germany. CEP. Consaltants, Edinburgh . 
Krkošek Payne S.J. and Gagnon G.A. (2014), Removal of acidic pharmaceuticals within a nitrifying recirculating biofilter, Journal of Hazardous Materials, 273, 85-93.

Lazarova V. (2000), Wastewater disinfection: assessment of the available technologies for water reclamation. Chapter In : Water conservation vol. 3 water management, Publication and conservation in arid climates, Ed. by M.F.A. Goosen and W.H. Shayya, Tchnomic publishing co. inc., pp. 171-198

Li Y., Zhu G., Ng W.J. and Tan S.K. (2014), A review on removing pharmaceutical contaminants from wastewater by constructed wetlands: Design, performance and mechanism, Science of the Total Environment, 468-469, 908-932

Lofrano G. and Brown J. (2010), Wastewater management through the ages: a history of humankind, Sci Tot Environ, 408, 5254-5264.

Maeda M., Nakada K., Kawamoto K. and Ikeda M. (1995), Area-wide use of reclaimed water in Tokyo, Japan, Proceedings on second international symposium on wastewater reclamation and reuse, Iraklio, Krete, Greece, October 17-20, pp.55-62.

Mascolo G., Balest L., Cassano D., Laera G., Lopez A., Pollice A. and Salerno C. (2010), Biodegradability of pharmaceutical industrial wastewater and formation of recalcitrant organic compounds during aerobic biological treatment, Bioresource Technology, 101, 2585-2591.

Oh D.L., Song J.H., Hwang S.J. and Kim J.W. (2009), Effects of adsorptive properties of biofilter packing materials on toluene removal, Journal of Hazardous materials, 170, 144-150.

Palma L.D. and Verdone N. (2009), The effect of disk rotational speed on oxygen transfer in rotating biological contractors, Bioresource Technology, 100, 1467-1470.

Pedrero F., Kalavrouziotis I.K., Alarcon J., Koukoulakis P. and Asano T. (2009), Use of treated municipal wastewater in irrigated agriculture- Review of the practices in Spain and Greece, Agricultural Water Management, 97(9), 1233-1241.

Saquaz M. and Pescod M.B. (1990), Microbiological performance of multi-stage stabilization ponds for effluent use in agriculture, Wat. Sci. Tech., 23, 1517-1524.

Schnitzer M. 1986, The synthesis, and chemical structure, reactions and functions of humic substances In: Humic substances (eds) Burns et al. REDA Edizioni per I' agricoltura, Milano, Italy.

Shelef G. and Halpenin R. (2002), The development of wastewater effluent quality requirements for reuse in agricultural irrigation in Israel, IWA regional symposium on water recycling in Mediterranean Region, Iraklio, Greece, 26-29 September, pp. 443-449.

Silvan C.G., Munoz M.M., Payatos J.M., Ramos A., Hontoria E., Rodelas B. and Lopez J.G. (2010), Structure of archael communities in membrane bioreactor and submerged biofilter wastewater treatment plants, Bioresource Technology, 101, 2096-2105.

Tahar A., Choubert J.M. and Coquery M. (2013), Xenobiotics removal by adsorption in the context of tertiary treatment: a mini review, Environ Sci Pollut Res, 20, 5085-5095.

Tahar A., Choubert J.M., Miège C., Esperanza M., Le Menach K., Budzinski H., Wisniewski C. and Coquery M. (2014), Removal of xenobiotics from effluent discharge by adsorption on zeolite and expanded clay: an alternative to activated carbon?, Environ Sci Pollut Res, 21, 5660-5668.

Villalobos G.G., Gamez G.M. and Herrera F.F. (1981), Program for the reuse of wastewater in Mexico, pp. 105-144. In: Municipal wastewater in agriculture. Academic press, New York.

Wang H.K. (1983), A study on the permissible toxicant level in agricultural utilization of sludge, Chinese Environmental Science, 3(5), 56-59.

Xing Z-P., Sun D-Z., Yu X-J., Zou J-L. and Zou W. (2014), Treatment of Antibiotic-fermantaion based pharmaceutical wastewater using anaerobic and aerobic moving, Bed biofilm reactors combined with ozone/hydrogen peroxide process, Environmental Progress and Sustainable Energy, 33(1), DOI 10.1002/cp 170April 2014.

Yang M. and Zheng S. (2014), Pollutant removal oriented yeast biomass production from high-organic-strength industrial wastewater: A review, Biomass and Bioenergy, (http://doi.org/10.1016/jbiombioe .2014.03.020)

Zhang L. and Liu Z. (1989), A methodological research on environmental impact assessment of sewage irrigation region, China Environ. Sci., 9, 298-303. 